\title{
Scale Dependence of Overconfidence in Stock Market Volatility Forecasts
}

\author{
Markus Glaser, Thomas Langer, Jens Reynders, Martin Weber*
}

June 27, 2007

\begin{abstract}
In this study, we analyze whether volatility forecasts (judgmental confidence intervals) are influenced by the specific elicitation mode (i.e. whether forecasters have to state future price levels or directly future returns as upper and lower bounds). We present questionnaire responses of about 250 students from two German universities. Participants were asked to state median forecasts as well as confidence intervals for seven stock market time series. Using a between subject design, one half of the subjects was asked to state future price levels, the other group was directly asked for returns. Consistent with prior research we find that subjects underestimate the volatility of stock returns, indicating overconfidence. As a new insight, we find that the strength of the overconfidence effect in stock market forecasts is highly significantly affected by the fact whether subjects provide price or return forecasts. Volatility estimates are lower (and the overconfidence bias is thus stronger) when subjects are asked for returns compared to price forecasts.
\end{abstract}

Keywords: Volatility forecast, confidence interval, individual investor, overconfidence.

JEL classification: C9, G1.

\footnotetext{
*Markus Glaser (corresponding author) is from the Lehrstuhl für Bankbetriebslehre, Business School, Universität Mannheim. Phone: +49 (0)621 181 3440. Fax: +49 (0)621 181 1534. E-mail: Glaser@bank.BWL.uni-mannheim.de. Thomas Langer is from the Finance Center, Universität Münster. Email: Thomas.Langer@wiwi.uni-muenster.de. Jens Reynders is from Siemens Management Consulting. Email: jens.reynders@siemens.com. Martin Weber is from the Lehrstuhl für Bankbetriebslehre, Business School, Universität Mannheim and CEPR, London. E-mail: Weber@bank.BWL.uni-mannheim.de. Financial Support from the Deutsche Forschungsgemeinschaft (DFG) is also gratefully acknowledged.
} 


\section{Introduction}

Numerous studies find that judgmental confidence intervals for uncertain quantities are too tight indicating overconfidence. But is the level of overconfidence easily influenced by the way people are asked to state interval judgments? This is the question we try to answer in this paper for the case of stock market volatility forecasts (judgmental confidence intervals): Is the width of the interval, i.e. the volatility forecast given by subjects, influenced by the specific elicitation mode (i.e. whether forecasters have to state future price levels or directly future returns)?

There are many questionnaire studies that elicit the volatility estimate of investors by asking for confidence intervals for the return or value of an index or the return or price of a stock in the future. These studies usually find that the intervals provided are too tight. Thus, historical volatilities are underestimated (see, for example, Glaser, Nöth and Weber (2004) and Hilton (2001)). The finding that confidence intervals for uncertain quantities are too tight is usually called "miscalibration" or “overconfidence” (see Lichtenstein, Fischhoff, and Phillips (1982), Soll and Klayman (2004), Griffin and Brenner (2004), and Glaser and Weber (2007)). ${ }^{1}$ However, there is no evidence in the literature so far that it matters for this question whether one asks for price levels or returns.

In this paper, we present questionnaire responses of about 250 students from two German universities. Participants were asked to state median forecasts as well as confidence intervals for seven stock market time series. Using a between subject design, one half of the subjects was asked to state future price levels, the other group was directly asked for returns.

We find that subjects underestimate the volatility of stock returns indicating overconfidence. The degree of overconfidence is highly significantly affected by the forecast mode. Volatility estimates are lower when subjects are asked for returns compared to the respective price forecasts.

The rest of the paper is organized as follows. In Section 2, we present the design of our study. Section 3 presents the results and the last section concludes.

\section{Design of the Study}

We designed different versions of a questionnaire that was filled out by students of two classes at the University of Mannheim and the University of Münster in Germany. The questionnaires can be downloaded from the following web page: <http://www.finanzierungslehrstuhl.de/glrw/GlaserLanger_Framing_supplement.pdf>

\footnotetext{
${ }^{1}$ Most behavioral models incorporate judgment biases into theories of financial markets by assuming that at least some market participants are overconfident in the way that they overestimate the precision of their knowledge or underestimate the variance of information signals. As a consequence, their confidence intervals for the value of a risky asset are too tight when compared to the rational benchmark. See Glaser, Nöth and Weber (2004) for an overview of overconfidence models in finance.
} 
Subjects were asked to state mean and interval judgments for seven time series with different trends over a one month and six month forecast horizon. As information, all subjects received the past six month chart. In four out of seven cases, subjects also received the name of the respective time series (i.e. the name of the stock or index). The two versions of the questionnaires only differed in the way we asked for the forecasts. Figures 1 and 2 show examples of the sample questions.

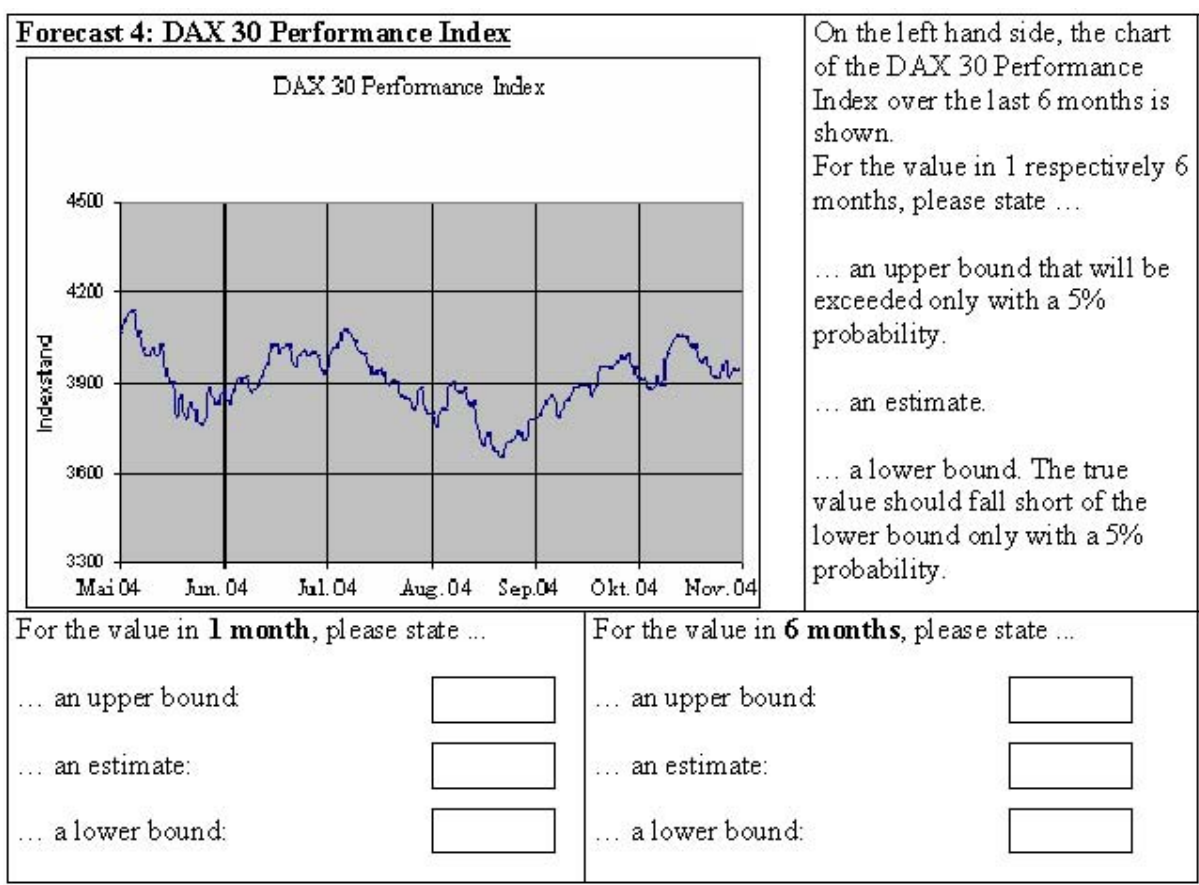

Figure 1: Questionnaire: Example from the Price Level Version.

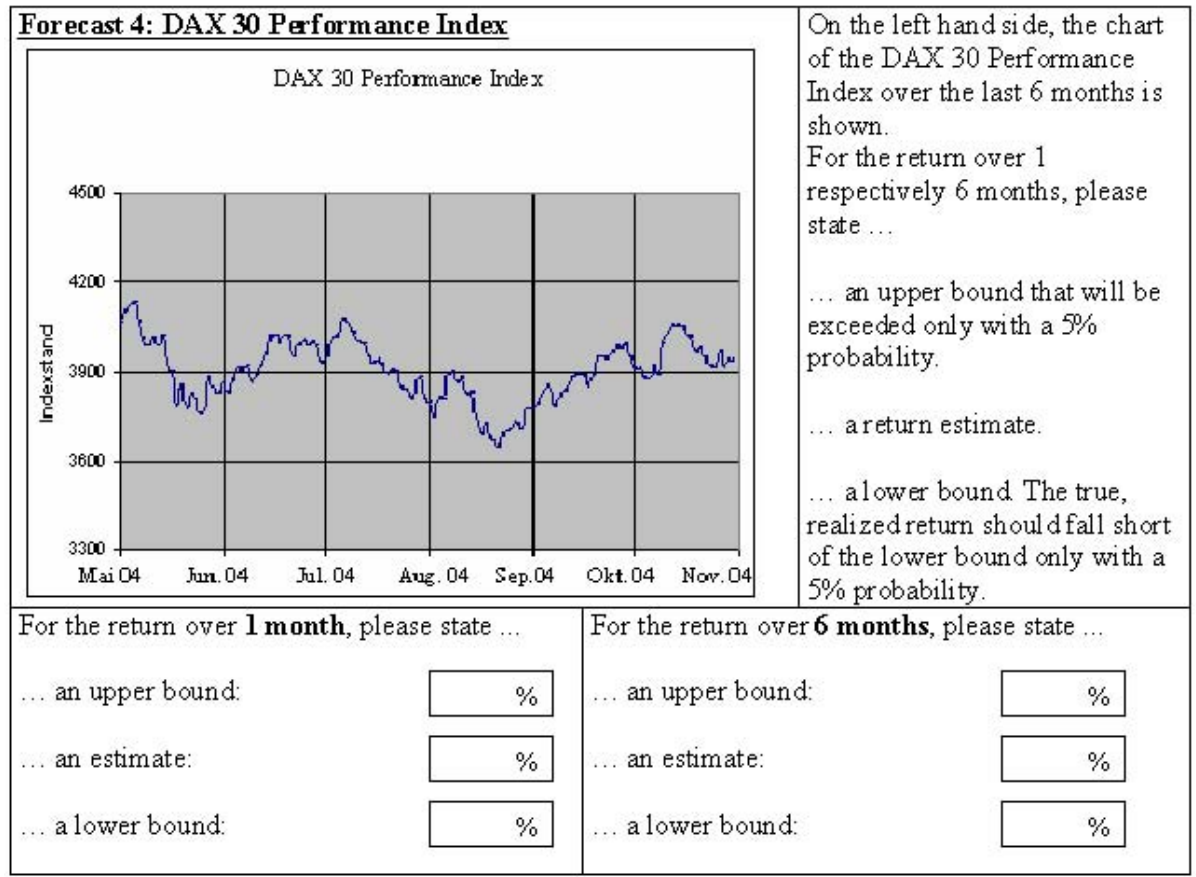

Figure 2: Questionnaire: Example from the Return Version. 
Glaser, Langer, Reynders, and Weber (2007) extensively describe the data set and subject pool of this questionnaire study. They show that the elicitation mode can help explain why some investors believe in mean reversion or trend continuation. However, they do not analyze scale dependence of overconfidence.

To calculate volatility forecasts, we proceed as follows (see also Glaser and Weber (2005) or Graham and Harvey (2003)). Means and volatility ${ }^{2}$ have not been surveyed directly, but can be approximated via the mean and upper and lower limits for continuous random variables (see Keefer and Bodily (1983)).

For each of the seven time series $i, i \in\{1 ; 2 ; 3 ; 4 ; 5 ; 6 ; 7\}$ and each subject $k, k \in\{1 ; \ldots ; 249\}$, mean and standard deviation are approximated using the following formula (price forecasts in the "price forecast mode" where converted to return forecasts $)^{3}$ :

$\operatorname{mean}_{i}^{k}=0,63 x(0,50)_{i}^{k}+0,185\left\lfloor x(0,05)_{i}^{k}+x(0,95)_{i}^{k}\right\rfloor$

standard deviation ${ }_{i}^{k}$

$=\sqrt{0,185\left(x(0,05)_{i}^{k}\right)^{2}+0,63\left(x(0,50)_{i}^{k}\right)^{2}+0,185\left(x(0,95)_{i}^{k}\right)^{2}-\left(\text { mean }_{i}^{k}\right)^{2}}$

$x(p)_{i}^{k}$ is the $p$ percentile of the distribution with $p \in\{0,05 ; 0,5 ; 0,95\}$.

\section{Results}

Table 1 presents means and medians across subjects of 1-month as well as 6-month volatility forecasts for each time series and for the two groups ("price forecast mode" and "return forecast mode"). Volatility forecasts are calculated as described in the section above. Furthermore, the table contains the difference of mean and median volatility forecasts of the "return forecast mode" and the "price forecast mode" as well as the p-value of a Mann-Whitney test. Null hypothesis is equality of populations. Median volatility forecasts are lower in the "return forecast mode" (except for the DAX) which is highly significant in most cases.

\footnotetext{
${ }^{2}$ From here on, we will use standard deviation and volatility synonymously.

${ }^{3}$ See Keefer and Bodily (1983), p. 597.
} 


\begin{tabular}{|c|c|c|c|c|c|c|}
\hline Stock & Trend & & $\begin{array}{c}\text { Price forecast } \\
\text { mode }\end{array}$ & $\begin{array}{c}\text { Return forecast } \\
\text { mode }\end{array}$ & $\begin{array}{c}\text { Difference } \\
\text { Return-Price } \\
\end{array}$ & $\begin{array}{c}\text { p-value } \\
\text { (Mann-Whitney) }\end{array}$ \\
\hline \multirow[t]{6}{*}{ BASF } & up & Mean (1 month) & 0.0449 & 0.0372 & -0.0077 & $<0.0001^{\star \star \star}$ \\
\hline & & Median (1 month) & 0.0437 & 0.0304 & & \\
\hline & & $\mathrm{N}$ & 125 & 119 & & \\
\hline & & Mean (6 months) & 0.0802 & 0.0633 & -0.0170 & $<0.0001^{\star \star \star}$ \\
\hline & & Median (6 months) & 0.0685 & 0.0480 & & \\
\hline & & $\mathrm{N}$ & 126 & 116 & & \\
\hline \multirow[t]{6}{*}{ Stock A (Schering) } & up & Mean (1 month) & 0.0452 & 0.0361 & -0.0092 & $0.0005^{\star \star \star}$ \\
\hline & & Median (1 month) & 0.0412 & 0.0304 & & \\
\hline & & $\mathrm{N}$ & 124 & 116 & & \\
\hline & & Mean (6 months) & 0.0875 & 0.0690 & -0.0185 & $0.0011^{\star * \star}$ \\
\hline & & Median (6 months) & 0.0701 & 0.0547 & & \\
\hline & & $\mathrm{N}$ & 128 & 116 & & \\
\hline \multirow{6}{*}{ Henkel } & down & Mean (1 month) & 0.0537 & 0.0392 & -0.0145 & $<0.0001^{\star \star \star}$ \\
\hline & & Median (1 month) & 0.0447 & 0.0308 & & \\
\hline & & $\mathrm{N}$ & 124 & 111 & & \\
\hline & & Mean (6 months) & 0.0921 & 0.0710 & -0.0211 & $<0.0001^{\star \star \star}$ \\
\hline & & Median (6 months) & 0.0832 & 0.0596 & & \\
\hline & & $\mathrm{N}$ & 127 & 116 & & \\
\hline \multirow[t]{6}{*}{ Stock C (Infineon) } & down & Mean (1 month) & 0.0831 & 0.0450 & -0.0380 & $<0.0001^{\star \star \star}$ \\
\hline & & Median (1 month) & 0.0733 & 0.0337 & & \\
\hline & & $\mathrm{N}$ & 125 & 115 & & \\
\hline & & Mean (6 months) & 0.1576 & 0.0831 & -0.0745 & $<0.0001^{\star \star \star}$ \\
\hline & & Median (6 months) & 0.1466 & 0.0670 & & \\
\hline & & $\mathrm{N}$ & 128 & 116 & & \\
\hline \multirow[t]{6}{*}{ DAX index } & flat & Mean (1 month) & 0.0252 & 0.0293 & 0.0040 & 0.6115 \\
\hline & & Median (1 month) & 0.0240 & 0.0243 & & \\
\hline & & $\mathrm{N}$ & 126 & 117 & & \\
\hline & & Mean (6 months) & 0.0448 & 0.0528 & 0.0080 & 0.8867 \\
\hline & & Median (6 months) & 0.0391 & 0.0356 & & \\
\hline & & $\mathrm{N}$ & 127 & 117 & & \\
\hline \multirow[t]{6}{*}{ Deutsche Telekom } & flat & Mean (1 month) & 0.0566 & 0.0371 & -0.0196 & $<0.0001^{\star \star \star}$ \\
\hline & & Median (1 month) & 0.0443 & 0.0304 & & \\
\hline & & $\mathrm{N}$ & 119 & 116 & & \\
\hline & & Mean (6 months) & 0.0958 & 0.0594 & -0.0365 & $<0.0001^{\star \star \star}$ \\
\hline & & Median (6 months) & 0.0823 & 0.0430 & & \\
\hline & & $\mathrm{N}$ & 125 & 117 & & \\
\hline \multirow[t]{6}{*}{ Stock B (SAP) } & flat & Mean (1 month) & 0.0381 & 0.0402 & 0.0020 & 0.9392 \\
\hline & & Median (1 month) & 0.0342 & 0.0315 & & \\
\hline & & $\mathrm{N}$ & 126 & 116 & & \\
\hline & & Mean (6 months) & 0.0633 & 0.0625 & -0.0007 & 0.1431 \\
\hline & & Median (6 months) & 0.0600 & 0.0496 & & \\
\hline & & $\mathrm{N}$ & 127 & 117 & & \\
\hline
\end{tabular}

Table 1: Volatility forecasts. $* * *$ indicates significance at the 1 percent level.

Furthermore, all 6-month volatility forecasts are higher than the respective 1-month volatility forecasts which is consistent with empirical observations (see Table 2). Table 2 once again presents means and medians across subjects of 1-month as well as 6-month volatility forecasts for each time series and for the two groups ("price forecast mode" and "return forecast mode"). Furthermore, the table presents historical volatilities for the time series that were known to the participants as well as chart volatilities for all seven time series. Historical volatilities are calculated as the standard deviations of non-overlapping 1-month respective 6-month returns from January 1990 to December 2004. ${ }^{4}$ To calculate chart volatilities, we first calculate the standard deviation of the 131 daily return observations for all seven time series. The 1-month chart volatility is the standard deviation of the daily return observations multiplied by $\sqrt{30}$. The 6-month chart volatility is the standard deviation of the daily return observations multiplied by $\sqrt{180}$. Note that during our sample period, chart volatilities are lower than the historical volatilities.

\footnotetext{
${ }^{4}$ The time series of Deutsche Telekom starts on November 18, 1996, the IPO date.
} 


\begin{tabular}{|c|c|c|c|c|c|c|c|c|c|c|}
\hline Stock & Trend & & $\begin{array}{l}\text { Price forecast } \\
\text { mode }\end{array}$ & $\begin{array}{l}\text { Return forecast } \\
\text { mode }\end{array}$ & $\begin{array}{l}\text { Historical } \\
\text { volatilities }\end{array}$ & $\begin{array}{c}\text { Chart } \\
\text { volatilities }\end{array}$ & $\begin{array}{c}\mathrm{OC} \\
\begin{array}{c}\text { Price forecast } \\
\text { mode }\end{array}\end{array}$ & $\begin{array}{c}\text { OC } \\
\text { Return forecast } \\
\text { mode }\end{array}$ & $\begin{array}{c}\text { p-value } \\
\text { (Mann-Whitney) } \\
\text { Price forecast } \\
\text { mode } \\
\end{array}$ & $\begin{array}{c}\text { p-value } \\
\text { (Mann-Whitney) } \\
\text { Return forecast } \\
\text { mode } \\
\end{array}$ \\
\hline \multirow[t]{6}{*}{ BASF } & up & Mean (1 month) & 0.0449 & 0.0372 & 0.0719 & 0.0571 & 0.64 & 2.06 & & \\
\hline & & Median (1 month) & 0.0437 & 0.0304 & & & 0.31 & 0.88 & $<0.0001^{\star \star \star}$ & $<0.0001^{\star \star \star}$ \\
\hline & & $\mathrm{N}$ & 125 & 119 & & & & & & \\
\hline & & Mean (6 months) & 0.0802 & 0.0633 & 0.1808 & 0.1400 & 1.49 & 4.17 & & \\
\hline & & Median (6 months) & 0.0685 & 0.0480 & & & 1.04 & 1.92 & $<0.0001^{\star \star \star}$ & $<0.0001^{\star \star \star}$ \\
\hline & & $\mathrm{N}$ & 126 & 116 & & & & & & \\
\hline \multirow[t]{6}{*}{ Stock A (Schering) } & up & Mean (1 month) & 0.0452 & 0.0361 & Stock was & 0.0652 & 1.00 & 2.25 & & \\
\hline & & Median (1 month) & 0.0412 & 0.0304 & unknown & & 0.58 & 1.14 & $<0.0001^{\star \star \star}$ & $<0.0001^{\star \star \star}$ \\
\hline & & & 124 & 116 & & & & & & \\
\hline & & Mean (6 months) & 0.0875 & 0.0690 & & 0.1596 & 1.75 & 3.61 & & \\
\hline & & Median (6 months) & 0.0701 & 0.0547 & & & 1.28 & 1.92 & $<0.0001^{\star \star \star}$ & $<0.0001^{\star \star \star}$ \\
\hline & & $\mathrm{N}$ & 128 & & & & & & & \\
\hline \multirow[t]{6}{*}{ Henkel } & down & Mean (1 month) & 0.0537 & 0.0392 & 0.0680 & 0.0674 & 0.74 & 1.98 & & \\
\hline & & Median (1 month) & 0.0447 & 0.0308 & & & 0.51 & 1.19 & $<0.0001^{\star \star \star}$ & $<0.0001^{\star \star \star}$ \\
\hline & & $\mathrm{N}$ & 124 & 111 & & & & & & \\
\hline & & Mean (6 months) & 0.0921 & 0.0710 & 0.1704 & 0.1651 & 1.41 & 3.78 & & \\
\hline & & Median ( 6 months) & 0.0832 & 0.0596 & & & 0.98 & 1.77 & $<0.0001^{\star \star \star}$ & $<0.0001^{\star \star \star}$ \\
\hline & & $\mathrm{N}$ & 127 & 116 & & & & & & \\
\hline \multirow[t]{6}{*}{ Stock C (Infineon) } & down & Mean (1 month) & 0.0831 & 0.0450 & Stock was & 0.1081 & 0.89 & 5.00 & & \\
\hline & & Median (1 month) & 0.0733 & 0.0337 & unknown & & 0.47 & 2.21 & $<0.0001^{\star \star \star}$ & $<0.0001^{\star \star \star}$ \\
\hline & & N & 125 & 115 & & & & & & \\
\hline & & Mean (6 months) & 0.1576 & 0.0831 & & 0.2649 & 1.50 & 7.53 & & \\
\hline & & Median ( 6 months) & 0.1466 & 0.0670 & & & 0.81 & 2.96 & $<0.0001^{\star \star \star}$ & $<0.0001^{\star \star \star}$ \\
\hline & & $\mathrm{N}$ & 128 & 116 & & & & & & \\
\hline \multirow[t]{6}{*}{ DAX index } & flat & Mean (1 month) & 0.0252 & 0.0293 & 0.0667 & 0.0553 & 1.96 & 2.40 & & \\
\hline & & Median (1 month) & 0.0240 & 0.0243 & & & 1.30 & 1.28 & $<0.0001^{\star \star \star}$ & $<0.0001^{\star \star \star}$ \\
\hline & & $\mathrm{N}$ & 126 & 117 & & & & & & \\
\hline & & Mean (6 months) & 0.0448 & 0.0528 & 0.1748 & 0.1355 & 4.02 & 4.83 & & \\
\hline & & Median (6 months) & 0.0391 & 0.0356 & & & 2.47 & 2.81 & $<0.0001^{\star \star \star}$ & $<0.0001^{\star \star \star}$ \\
\hline & & $\mathrm{N}$ & 127 & 117 & & & & & & \\
\hline \multirow{6}{*}{ Deutsche Telekom } & flat & Mean (1 month) & 0.0566 & 0.0371 & 0.1272 & 0.0662 & 0.48 & 2.60 & & \\
\hline & & Median (1 month) & 0.0443 & 0.0304 & & & 0.49 & 1.18 & $<0.0001^{\star \star \star}$ & $<0.0001^{\star \star \star}$ \\
\hline & & $\mathrm{N}$ & 119 & 116 & & & & & & \\
\hline & & Mean (6 months) & 0.0958 & 0.0594 & 0.3430 & 0.1620 & 1.35 & 6.25 & & \\
\hline & & Median (6 months) & 0.0823 & 0.0430 & & & 0.97 & 2.77 & $<0.0001^{\star \star \star}$ & $<0.0001^{\star \star \star}$ \\
\hline & & $\mathrm{N}$ & 125 & 117 & & & & & & \\
\hline \multirow[t]{6}{*}{ Stock B (SAP) } & flat & Mean (1 month) & 0.0381 & 0.0402 & Stock was & 0.0933 & 2.44 & 3.16 & & \\
\hline & & Median (1 month) & 0.0342 & 0.0315 & unknown & & 1.73 & 1.96 & $<0.0001^{\star \star \star}$ & $<0.0001^{\star \star \star}$ \\
\hline & & $\mathrm{N}$ & 126 & 116 & & & & & & \\
\hline & & Mean (6 months) & 0.0633 & 0.0625 & & 0.2285 & 4.41 & 7.06 & & \\
\hline & & Median (6 months) & 0.0600 & 0.0496 & & & 2.81 & 3.61 & $<0.0001^{\star \star *}$ & $<0.0001^{\star \star \star}$ \\
\hline & & $\mathrm{N}$ & 127 & 117 & & & & & & \\
\hline
\end{tabular}

Table 2: Volatility forecasts, historical volatilities, chart volatilities, and overconfidence (OC). *** indicates significance at the 1 percent level.

Table 2 also shows that volatility estimates are lower than historical volatilities or chart volatilities. Historical volatilities are often used as an objective volatility benchmark or an estimate for the future volatility (see for example, De Bondt (1998), Graham and Harvey (2003), and Glaser and Weber $(2005))^{5}$. The fact that confidence intervals are too tight or, in other words, that people underestimate the volatility of stock returns, is called overconfidence. To analyze overconfidence more formally, we calculate an overconfidence measure for each subject and time series as follows: OC=(chart volatility/volatility forecast)-1. A positive OC measure indicates overconfidence, a negative measure underconfidence. Table 2 shows, that all OC measures are highly significantly positive. We are thus able to confirm the usual result in the literature (see, for example, Hilton (2001) or Graham and Harvey (2003)). Table 2 also shows that overconfidence is stronger for 6-month forecasts. This result is consistent with Glaser, Langer, and Weber (2005) who show that overconfidence in volatility forecasts is stronger, the longer the forecast horizon.

\footnotetext{
${ }^{5}$ Furthermore, historical volatilities are often regarded as the best time-series volatility-forecasting method when compared to GARCH or stochastic volatility (see Poon and Granger (2005)).
} 


\section{Discussion and Conclusion}

The main results of this paper can be summarized as follows: Subjects underestimate the volatility of stock returns indicating overconfidence. Overconfidence in stock market forecasts is highly significantly affected by the fact whether one asks for prices or returns. Volatility estimates are lower and overconfidence is higher when subjects are asked for returns compared to price forecasts.

Our study draws attention on a determinant of overconfidence that is neglected in the literature so far. Studies analyze, for example, the influence of time series characteristics on volatility forecast (see the survey by Lawrence, Goodwin, O'Connor, and Önkal (2006) or Du and Budescu (2007) as a recent example). Scale dependence of overconfidence was not analyzed before.

Future research should investigate why we document such a strong scale dependence. One avenue for future research is provided by Amromin and Sharpe (2006) and Glaser, Langer, Reynders, and Weber (2007). They present evidence that investors seem to be reluctant to state negative numbers. As a consequence, investors realize a greater downside potential when they have to state price levels which would results in wider confidence intervals. 


\section{References}

Amromin, G. and Sharpe, S. A (2006), From the Horse's Mouth: Gauging Conditional Expected Stock Returns from Investor Survey, Working Paper, Federal Reserve Board Washington

De Bondt, W. F. (1998) A portrait of the individual investor, European Economic Review 42, 831844.

Du, N., and D. V. Budescu (2007), Does past volatility affect investors' price forecasts and confidence judgments?, International Journal of Forecasting, forthcoming.

Glaser, M., T. Langer, J. Reynders, and M. Weber (2007), Framing Effects in Stock Market Forecasts: The Difference Between Asking for Prices and Asking for Returns, Review of Finance 11, 325—357.

Glaser, M., Langer, T. and Weber, M. (2005), Overconfidence of Professionals and Lay Men: Individual Differences Within and Between Tasks? Working Paper, University of Mannheim.

Glaser, M., Nöth, M. and Weber, M. (2004), Behavioral Finance, in: Koehler, D. J. and N. Harvey (eds.), Blackwell Handbook of Judgment and Decision Making, Blackwell (Malden), 527—546.

Glaser, M. and M. Weber (2007), Overconfidence and Trading Volume, Geneva Risk and Insurance Review, forthcoming.

Glaser, M. and Weber, M. (2005), September 11 and Stock Return Expectations of Individual Investors, Review of Finance 9, 24-279.

Graham, J. R. and Harvey, C. R. (2003) Expectations of equity risk premia, volatility and asymmetry, Working paper, Fuqua School of Business, Duke University.

Griffin, D. and Brenner, L. (2004) Perspectives on probability judgment calibration, in Koehler, D. J. and N. Harvey (eds.), Blackwell Handbook of Judgment and Decision Making, Blackwell (Malden), 177-199. 
Hilton, D. J. (2001) The psychology of financial decision-making: Applications to trading, dealing, and investment analysis, Journal of Psychology and Financial Markets 2, 37—53.

Keefer, D. L. and Bodily, S. E. (1983) Three-point approximations for continuous random variables, Management Science 29, 595-609.

Lawrence, M., Goodwin, P-, O'Connor, M., and Önkal, D. (2006), Judgmental forecasting: A review of progress over the last 25 years, International Journal of Forecasting 22, 493—518.

Lichtenstein, S., Fischhoff, B. and Phillips, L. D. (1982) Calibration of probabilities: The state of the art to 1980, in Kahneman, D., P. Slovic and A. Tversky (eds.), Judgment under Uncertainty: Heuristics and Biases, Cambridge University Press (Cambridge), 306-334.

Poon, S.-H. and Granger, C. (2005), Practical Issues in Forecasting Volatility, Financial Analysts Journal 61, 45-56.

Soll, J. B. and Klayman, J. (2004) Overconfidence in interval estimates, Journal of Experimental Psychology: Learning, Memory, and Cognition 30, 299-314. 